\title{
Microbiological Profiling of Imported Apples and Demonstration of Bacterial Survival Capacity through in vitro Challenge Test
}

\author{
Nour Fatema, Mrityunjoy Acharjee, Rashed Noor* \\ Department of Microbiology, Stamford University Bangladesh,Siddeswari Road, Dhaka, Bangladesh \\ *Corresponding author: noor.rashed@yahoo.com
}

Received November 18, 2013; Revised November 25, 2013; Accepted December 08, 2013

\begin{abstract}
Present study conducted a complete investigation on microorganisms contaminating the imported apples commonly consumed in Dhaka metropolis, Bangladesh. Study of microbial prevalence demonstrated a substantial number of total viable bacteria $\left(\sim 10^{7} \mathrm{cfu} / \mathrm{g}\right)$ in each of the dissected portions, i. e., surface, body and core of the samples except for the body and core portion of Malus paulared (Paula Red). Among the specific pathogens, Staphylococcus spp. was found to be predominant within a range of $1.6 \times 10^{5}-2.8 \times 10^{7} \mathrm{cfu} / \mathrm{g}$, while Escherichia coli, Klebsiella spp., Salmonella spp., Shigella spp., Pseudomonas spp., Vibrio spp. and Listeria spp. were also identified. Fungal contamination $\left(\sim 10^{6} \mathrm{cfu} / \mathrm{g}\right)$ was observed only in the surface of each of the categories of apple samples tested. Study of antibiogram showed that most of the bacterial isolates were multi-drug resistant (MDR); however, study of antimicrobial activity showed that the Malus pumila (Golden delicious apple) samples possessed the anti-bacterial effect against Vibrio spp. Further studies employing the in vitro challenge test revealed a decline trend in the survival potential of spoiling bacteria in the apple samples tested.
\end{abstract}

Keywords: apple, food quality, food safety microorganisms, microbial challenge test

Cite This Article: Nour Fatema, Mrityunjoy Acharjee, and Rashed Noor, "Microbiological Profiling of Imported Apples and Demonstration of Bacterial Survival Capacity through in vitro Challenge Test." American Journal of Microbiological Research 1, no. 4 (2013): 98-104. doi: 10.12691/ajmr-1-4-6.

\section{Introduction}

Apples comprise an exclusive popularity with their anti-oxidant traits with the capacity to reduce the risk of various diseases $[1,2]$. However, these widely consumed fruits may get contaminated when they come in contact with soil, air, water or animal wastes during cultivation, transportation and further processing \& handling $[3,4]$. Microorganisms may gain access more frequently to the surface of the fresh produce due to poor handling in stores and retail markets $[3,4,5]$. Presence of bacterial isolates including Escherichia coli, Salmonella spp., and Shigella spp. possesses a potential risk of food borne illness to consumers $[5,6,7,8]$. Another important health related concern on fruit consumption lies on the prevalence of drug resistant microorganisms which is known to extensively hamper the disease medication [9-14]. On the contrary, the probable anti-bacterial trait of the consumable fruits may aid in the overall public health maintenance $[15,16]$.

A relatively new aspect further to be considered in the overall quality and safety measurement of a food sample is to assess the microbial survival potential in selected foods, through microbiological challenge test, which involves the inoculation of specific microorganisms into a product followed by incubation of the product under controlled environmental conditions [17,18,19]. Such type of in vitro challenge tests may focus on the growth potential of specific organisms and estimate the maximum growth rate [20]. Thus, the test can infer on the food stability as well as the consumer safety.

While a number of studies have been conducted on apple microbiology, investigations on the survival of microorganisms in apple samples are still limiting [21,22]. Demonstrating the growth sustainability of microorganisms in this particular fruit may engender imperative data on food hygiene and safety, as well as may predict on the further intoxication posed by different pathogens present in the samples. Based on these facts and considerations, present study endeavored (1) to ascertain and enumerate the apple spoiling microorganisms with their drug-resistance traits, (2) to reveal the anti-bacterial activity of the samples tested, and finally (3) to pertain the in vitro microbial challenge of the apple samples in order to explore the extent of viability of spoiling microflora in apples.

\section{Materials and Methods}

\subsection{Study Area, Sampling and Sample Processing}

The study was carried out with 5 categories of imported apple samples including Malus domestica (Gala), Malus 
pumila (Golden Delicious), Malus pumila (Fuji), Malus domestica (Red Delicious) and Malus paulared (Paula Red) originating from New Zealand, West Virginia, Japan, Peru and Sparta, consecutively. Samples were randomly collected from different shops located in Dhaka city within a time frame from April 2013 to September 2013 following standard protocol [23]. For the identification and enumeration of contaminating bacteria and fungi, $10 \mathrm{~g}$ of each sample was homogenized with $90 \mathrm{ml}$ buffer peptone water $(\mathrm{pH} 7.2 \pm 0.2)$ and diluted up to $10^{-5}$.

\subsection{Isolation and Enumeration of Spoiling Microorganisms}

The primary inoculation was performed by the conventional culture technique with the addition of $0.1 \mathrm{ml}$ of each sample onto nutrient agar (NA) and Sabouraud's dextrose agar (SDA) for total viable bacteria (TVB) and total fungal load, respectively, following spread plate technique [24]. Plates were incubated at optimum temperature followed as $37^{\circ} \mathrm{C}$ for 24 hours and at $25^{\circ} \mathrm{C}$ for 48 hours for total viable bacteria (TVB) and fungi, respectively.

From the dilutions $10^{-3}$ and $10^{-5}$, samples $(0.1 \mathrm{ml})$ were spread onto MacConkey agar and membrane fecal coliform agar (M-FC) for the enumeration of coliforms (especially, Escherichia coli and Klebsiella spp.) and fecal coliforms, respectively. Afterward, the MacConkey agar plates were incubated at $37^{\circ} \mathrm{C}$ for 24 hours while for estimating the fecal coliforms, incubation at $44.5{ }^{\circ} \mathrm{C}$ for 24 hours was carried out. Eosin methylene blue (EMB) agar media were further used for the observation of production of green metallic sheen (if any) characteristic of $E$. coli strains. An aliquot of $0.1 \mathrm{ml}$ of diluted sample was spread onto mannitol salt agar (MSA) and Pseudomonas agar for the isolation of Staphylococcus spp. and Pseudomonas spp., respectively and incubated at $37^{\circ} \mathrm{C}$ for 24 hours. For the enumeration of Listeria spp., $0.1 \mathrm{ml}$ of suspension was spread onto the Listeria identification media and plates were incubated at $37^{\circ} \mathrm{C}$ for 24 hours. Listeria spp. was identified as blue-green colonies on Listeria identification agar media with a further confirmation by biochemical tests [25].

\subsubsection{Enrichment for Enumeration of Salmonella spp., Shigella spp. and Vibrio spp}

Prior to quantify the relatively stressed cells or the viable but non-culturable (VBNC) microbial cells, $1 \mathrm{ml}$ of sample was transferred into $9 \mathrm{ml}$ of seleniote cysteine broth and alkaline peptone water (APW) for the enrichment of Salmonella, Shigella, and vibrio spp., respectively and incubated at $37^{\circ} \mathrm{C}$ for 6 hours $[12,26,27,28]$. After incubation, the samples were diluted up to $10^{-5}$ and then $0.1 \mathrm{ml}$ of samples from $10^{-3}$ and $10^{-5}$ dilutions were spread onto Salmonella- Shigella (SS) agar and the thiosulfate citrate bile salt sucrose (TCBS) agar for the isolation of Salmonella and Shigella spp, and Vibrio spp., respectively. Plates were incubated at $37^{\circ} \mathrm{C}$ for 48 hours for the detection of typical colonies. Finally, all the isolates were biochemically examined following standard procedures [12,24,29].

\subsection{Antibiotic Susceptibility Test}

All the bacterial isolates were examined for their antibiotic susceptibility traits against 16 first, second and third generation antibacterial drugs by the disc diffusion assay on Mueller-Hinton agar (Difco, Detroit, MI) [12,30,31,32]. Antibiotic discs used in the study included: trimethoprim/sulfamethoxazole (25 $\mu \mathrm{g})$, erythromycin (15 $\mu \mathrm{g})$, amoxicillin (30 $\mu \mathrm{g})$, ceftriaxone $(30 \mu \mathrm{g})$, ciprofloxacin $(5 \mu \mathrm{g})$, streptomycin $(10 \mu \mathrm{g})$, ampicillin (10 $\mu \mathrm{g})$, tetracycline (30 $\mu \mathrm{g})$, chloramphenicol (30 $\mu \mathrm{g})$, cefixime (5 $\mu \mathrm{g})$, polymyxin b (300 units), kanamycin (30 $\mu \mathrm{g})$, vancomycin $(30 \mu \mathrm{g})$, gentamicin $(10 \mu \mathrm{g})$, nalidixic acid (30 $\mu \mathrm{g})$, azithromycin $(15 \mu \mathrm{g})$ and penicillin $\mathrm{G}(10$ $\mu g)$.

\subsection{Determination of Antibacterial Activity of Apple Samples}

Antibacterial activity was determined by using the agar well diffusion methods previously used by [16,33,34]. Normal saline suspensions of test organisms (Pseudomonas spp., Listeria spp., Aeromonas spp., Vibrio spp., Salmonella spp., Klebsiella spp., Staphylococcus aureus, E. coli) consisting of $10^{6}$ cells/mL (compared with McFarland standard) were introduced on separate MullerHinton agar and lawns of test organisms were prepared. After drying, sterile cork borers were used to create $8 \mathrm{~mm}^{3}$ wells. A volume of $100 \mu \mathrm{L}$ of each sample blend (with a concentration of $11 \mu \mathrm{g} / \mu \mathrm{L}$ ) was poured into separate wells, dried and then incubated at $37^{\circ} \mathrm{C}$ for $12-18$ hours. Normal saline and Chloramphenicol $(10 \mu \mathrm{g})$ were used as negative and positive controls, respectively. Presence of clear zone around the sample solution (if any) indicated the presence of antibacterial activity [35].

\subsection{Microbial Challenge Test}

\subsubsection{Samples Processing}

The surface of the two selected apple samples (Gala and Golden Delicious) were made free of microorganisms by washing with distilled water followed by $90 \%$ ethanol wash for at least 5 times. $10 \mathrm{~g}$ samples were then blended with $90 \mathrm{ml}$ buffered peptone water (BPW), and from the resulting suspensions, each $10 \mathrm{ml}$ aliquot was centrifuged at $5000 \mathrm{~g}$ for 5 minutes for 3 times, the resulting pellet was further washed by $90 \%$ ethanol for 2 times followed by final washing with $70 \%$ alcohol. The resulting pellets were collected and re-suspended with $9 \mathrm{ml} \mathrm{BPW}$ and 100 $\mu \mathrm{L}$ of each sample was introduced on to nutrient agar media to examine the remaining growth for the assurance of complete elimination of intrinsic contaminating microorganisms. Samples were stored in $-4^{\circ} \mathrm{C}$ until use.

\subsubsection{Inoculation and Enumeration of Microbial Growth}

One loop full of the each pure culture of E. coli, Klebsiella spp., Staphylococcus spp., Pseudomonas spp., Salmonella spp, and Aeromonas spp. were transferred into $9 \mathrm{ml}$ sterile normal saline containing tubes separately by means of direct contact method [24]. After 6 hours of incubation at $37^{\circ} \mathrm{C}$ [36], the cell density of each test bacterial suspension reached to approximately $10^{5} / \mathrm{g}$ (compared with McFarland Standard OD 0.5). The challenge test was carried out with each of those bacterial suspensions. Each of the apple suspensions $(10 \mathrm{ml})$ was 
inoculated with $100 \mu \mathrm{l}$ of the bacterial suspension (with the initial load of $\sim 10^{5} \mathrm{cfu} / \mathrm{g}$ ), and incubated at $37^{\circ} \mathrm{C}$ for 15 days. Control samples were kept un-inoculated. Subsequently, the samples were diluted up to $10^{-6}$ and plated onto Luria Bertani (LB) agar for the investigation of the growth pattern of the isolates at every 24-hour following standard spread plate technique [24,36].

\subsubsection{Assessment of Reduction in Bacterial Load}

For the detection of simulation effect, i. e., the probable growth enhancement or the decay of the artificially grown bacterial species in the apple samples studied, the log reduction and the percent reduction were estimated [20]. As the initial load at 0 hour of inoculation was around $10^{5}$ cfu/g which in real had been artificially introduced into the media, the maximal load (cfu/g) after 24-48 hours was considered instead of that initial load (cfu/g) in order to estimate the growth decay. Thus deducing the final load (cfu/g) from the maximum growth (cfu/g) point would infer the accurate decay pattern of microorganisms, which in turn might reveal the bacterial survival potential as well as the product stability in microbiological aspect.

\subsection{Statistical Analysis}

Experiments were carried out independently 3 times. All respected values were statistically analyzed by determining the $\mathrm{p}$-value through $t$ test [12].

\section{Results}

\subsection{Microbial Prevalence in the Apple Sample Tested}

Almost all the samples were found to be largely contaminated by bacteria and fugal population, of which staphylococcal proliferation was the most significant (Table 1). Gala, Golden Delicious, and Paufia Red apple samples were found to be contaminated with $E$. coli $\left(>10^{6}\right.$ cfu/g). Klebseilla spp. and Salmonella spp. were prevailing in Fuji apple samples (maximum of $10^{5} \mathrm{cfu} / \mathrm{g}$ and $10^{4} \mathrm{cfu} / \mathrm{g}$, respectively). Gala and Fuji samples were found to be contaminated with Pseudomonas spp. $\left(1.6 \times 10^{7} \mathrm{cfu} / \mathrm{g}\right)$ and Shigella spp. $\left(4.0 \times 10^{3} \mathrm{cfu} / \mathrm{g}\right)$. All the samples were totaly free from the contamination of Vibrio spp. (Table 1).

Table 1. Isolation and enumeration of microorganisms in the imported apple samples tested

\begin{tabular}{|c|c|c|c|c|c|c|c|c|c|}
\hline Sample & Fractions & $\begin{array}{l}{ }^{\mathrm{a}} \mathrm{TVC} \\
(\mathrm{cfu} / \mathrm{g})\end{array}$ & $\begin{array}{l}\text { Fungi } \\
\text { (cfu/g) }\end{array}$ & $\begin{array}{l}\text { E. coli } \\
(\mathrm{cfu} / \mathrm{g})\end{array}$ & $\begin{array}{c}\text { Klebsiella } \\
\text { spp. } \\
\text { (cfu/g) }\end{array}$ & $\begin{array}{c}{ }^{\mathrm{b}} \text { Salmonella } \\
\text { spp. } \\
\text { (cfu/g) }\end{array}$ & $\begin{array}{l}{ }^{\circ} \text { Shigella } \\
\text { spp. } \\
\text { (cfu/g) }\end{array}$ & $\begin{array}{c}\text { Staphylococcus } \\
\text { spp. } \\
\text { (cfu/g) } \\
\end{array}$ & $\begin{array}{c}\text { Pseudomonas } \\
\text { spp. } \\
\text { (cfu/g) }\end{array}$ \\
\hline \multirow{3}{*}{ Gala $(n=5)$} & Surface & $3.2 \times 10^{7}$ & $1.9 \times 10^{6}$ & $9.6 \times 10^{6}$ & 0 & 0 & 0 & $6.2 \times 10^{6}$ & $1.6 \times 10^{7}$ \\
\hline & Body & $9.1 \times 10^{6}$ & 0 & $1.3 \times 10^{4}$ & 0 & 0 & 0 & $3.3 \times 10^{5}$ & 0 \\
\hline & Core & $7.3 \times 10^{6}$ & 0 & $2.0 \times 10^{5}$ & 0 & 0 & 0 & $3.2 \times 10^{5}$ & 0 \\
\hline \multirow{3}{*}{$\begin{array}{l}\text { Golden Delicious } \\
\qquad(\mathrm{n}=5)\end{array}$} & Surface & $4.8 \times 10^{7}$ & $7.3 \times 10^{5}$ & $4.3 \times 10^{4}$ & 0 & 0 & 0 & $5.0 \times 10^{6}$ & 0 \\
\hline & Body & $8.7 \times 10^{6}$ & 0 & 0 & 0 & 0 & 0 & $9.6 \times 10^{5}$ & 0 \\
\hline & Core & $1.4 \times 10^{6}$ & 0 & 0 & 0 & 0 & 0 & $1.2 \times 10^{5}$ & 0 \\
\hline \multirow{3}{*}{ Fuji (n=5) } & Surface & $1.6 \times 10^{7}$ & $2.4 \times 10^{6}$ & 0 & $1.5 \times 10^{5}$ & 0 & $4.0 \times 10^{3}$ & $1.6 \times 10^{7}$ & 0 \\
\hline & Body & $1.4 \times 10^{6}$ & 0 & 0 & $1.1 \times 10^{4}$ & $2.5 \times 10^{4}$ & 0 & $1.4 \times 10^{6}$ & 0 \\
\hline & Core & $1.6 \times 10^{5}$ & 0 & 0 & 0 & 0 & 0 & $1.2 \times 10^{6}$ & 0 \\
\hline \multirow{3}{*}{$\begin{array}{l}\text { Red Delicious } \\
\qquad(n=5)\end{array}$} & Surface & $3.0 \times 10^{7}$ & $2.6 \times 10^{6}$ & 0 & 0 & 0 & 0 & $9.2 \times 10^{6}$ & 0 \\
\hline & Body & $3.2 \times 10^{6}$ & 0 & 0 & 0 & 0 & 0 & $1.2 \times 10^{5}$ & 0 \\
\hline & Core & $4.0 \times 10^{5}$ & 0 & 0 & 0 & 0 & 0 & $1.5 \times 10^{5}$ & 0 \\
\hline \multirow{3}{*}{ Paula Red (n=5) } & Surface & $1.6 \times 10^{7}$ & $8.5 \times 10^{5}$ & $3.0 \times 10^{5}$ & 0 & 0 & 0 & $6.0 \times 10^{7}$ & 0 \\
\hline & Body & 0 & 0 & 0 & 0 & 0 & 0 & $3.0 \times 10^{6}$ & 0 \\
\hline & Core & 0 & 0 & 0 & 0 & 0 & 0 & $2.8 \times 10^{6}$ & 0 \\
\hline
\end{tabular}

Experiments were performed in triplicates and the results were reproducible. ${ }^{\mathrm{a}} \mathrm{TVC}$ - Total viable bacteria. ${ }^{\mathrm{b}}$ Bacterial load after enrichment (prior to enrichment, the recovery was nil). E. coli and Klebsiella spp. articulated the coliform group. Fecal coliform, Vibrio and Listeria spp. were completely absent in all samples.

\subsection{Drug-resistance Traits of the Isolates and the Anti-bacterial Activity against Vibrio spp.}

Study of antibiogram revealed that most of the isolates were highly resistant against ampicillin $(10 \mu \mathrm{g})$, ciprofloxacin $(5 \mu \mathrm{g})$, ceftriaxone $(30 \mu \mathrm{g})$, penicillin $(10$ $\mu \mathrm{g})$, nalidixic acid $(30 \mu \mathrm{g})$, and vancomycin $(30 \mu \mathrm{g})$ (Table 2). In contrast, most of the isolates were found to retain higher sensitivity against imipenem (30 $\mu \mathrm{g})$, gentamicin, trimethoprim-sulfamethoxazole and azithromycin $(15 \mu \mathrm{g})$. In addition, most of the isolates were found to be multi drug resistant against ampicillin

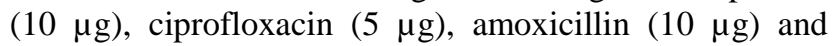
chloramphenicol (10 $\mu \mathrm{g})$ (Table 2). However, further study with sample blends demonstrated an anti-bacterial activity by the Golden Delicious samples against Vibrio spp. with a zone size of inhibition of $20 \mathrm{~mm}$.

\subsection{Bacterial Survival Potential as Observed through the In vitro Challenge Test}

After inoculating the Gala and Golden Delicious apple samples with each of the 6 test bacteria separately, an initial increase in growth around 48 hours was observed followed by a decreasing trend (Figure 1). As stated earlier, since the initial inoculum was artificially introduced within an average load of $10^{5}$ cells/g, the maximal growth points were considered in order to compare with the final microbial load after 15 days (Figure 1 and Figure 2). In Gala samples (Figure 1A-F), reduction of bacteria was scored more than 2-log for Pseudomonas spp., while Salmonella spp., Klebsiealla spp., E. coli and Aeromonas spp. also reduced by nearly 2log. Even minor, Staphylococcus spp. was also found to 
be reduced approximately to $1-\log$ in these samples (Figure 2A).

Table 2. Antimicrobial susceptibility pattern of different pathogenic isolates

\begin{tabular}{|c|c|c|c|c|c|c|c|c|c|c|c|c|}
\hline \multirow{2}{*}{$\begin{array}{l}\text { Organisms } \\
{ }^{a} \text { Antibiotics }\end{array}$} & \multicolumn{2}{|c|}{$\begin{array}{c}\text { E. coli } \\
\mathrm{n}=5\end{array}$} & \multicolumn{2}{|c|}{$\begin{array}{c}\text { Klebsiella spp. } \\
\mathrm{n}=2\end{array}$} & \multicolumn{2}{|c|}{$\begin{array}{c}\text { Shigella spp. } \\
\quad \mathrm{n}=1\end{array}$} & \multicolumn{2}{|c|}{$\begin{array}{c}\text { Salmonella spp. } \\
\mathrm{n}=1\end{array}$} & \multicolumn{2}{|c|}{$\begin{array}{c}\text { Pesudomonas spp. } \\
n=1\end{array}$} & \multicolumn{2}{|c|}{$\begin{array}{c}\text { Staphylococcus spp. } \\
n=15\end{array}$} \\
\hline & $\mathrm{R}$ & $\mathrm{S}$ & $\mathrm{R}$ & $\mathrm{S}$ & $\mathrm{R}$ & $\mathrm{S}$ & $\mathrm{R}$ & $\mathrm{S}$ & $\mathrm{R}$ & $\mathrm{S}$ & $\mathrm{R}$ & $\mathrm{S}$ \\
\hline AMP $(10 \mu \mathrm{g})$ & $25 \%$ & $75 \%$ & $100 \%$ & $0 \%$ & $100 \%$ & $0 \%$ & $100 \%$ & $0 \%$ & $100 \%$ & $0 \%$ & $99 \%$ & $1 \%$ \\
\hline CIP $(5 \mu \mathrm{g})$ & $60 \%$ & $40 \%$ & $100 \%$ & $0 \%$ & $0 \%$ & $100 \%$ & $100 \%$ & $0 \%$ & $100 \%$ & $0 \%$ & ND & ND \\
\hline 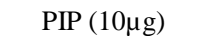 & $30 \%$ & $70 \%$ & $100 \%$ & $0 \%$ & ND & ND & ND & ND & $0 \%$ & $100 \%$ & $90 \%$ & $10 \%$ \\
\hline CEF $(30 \mu \mathrm{g})$ & $67 \%$ & $33 \%$ & $100 \%$ & $0 \%$ & $0 \%$ & $100 \%$ & $0 \%$ & $100 \%$ & $0 \%$ & $100 \%$ & ND & ND \\
\hline AMO $(10 \mu \mathrm{g})$ & $33 \%$ & $67 \%$ & $100 \%$ & $0 \%$ & $0 \%$ & $100 \%$ & $0 \%$ & $100 \%$ & $100 \%$ & $0 \%$ & $100 \%$ & $1 \%$ \\
\hline 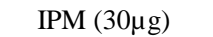 & $0 \%$ & $100 \%$ & $0 \%$ & $100 \%$ & $0 \%$ & $100 \%$ & $0 \%$ & $100 \%$ & $0 \%$ & $100 \%$ & ND & ND \\
\hline PEN $(10 \mu \mathrm{g})$ & ND & ND & ND & ND & ND & ND & $100 \%$ & $0 \%$ & ND & ND & $99 \%$ & $1 \%$ \\
\hline CHL $(10 \mu \mathrm{g})$ & $45 \%$ & $55 \%$ & $50 \%$ & $50 \%$ & $100 \%$ & $0 \%$ & $0 \%$ & $100 \%$ & $100 \%$ & $0 \%$ & $\mathrm{ND}$ & ND \\
\hline TMP-SUL $(25 \mu \mathrm{g})$ & $20 \%$ & $80 \%$ & $50 \%$ & $50 \%$ & $0 \%$ & $100 \%$ & $0 \%$ & $100 \%$ & $0 \%$ & $100 \%$ & $30 \%$ & $70 \%$ \\
\hline GEN $(10 \mu \mathrm{g})$ & ND & ND & ND & ND & $0 \%$ & $100 \%$ & $0 \%$ & $100 \%$ & $0 \%$ & $100 \%$ & $34 \%$ & $66 \%$ \\
\hline AZI $(15 \mu \mathrm{g})$ & ND & ND & ND & ND & ND & ND & $0 \%$ & $100 \%$ & ND & ND & ND & ND \\
\hline KNA $(30 \mu \mathrm{g})$ & ND & ND & ND & ND & ND & ND & $0 \%$ & $100 \%$ & ND & ND & ND & ND \\
\hline 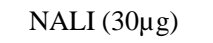 & $85 \%$ & $15 \%$ & $50 \%$ & $50 \%$ & $100 \%$ & $0 \%$ & $0 \%$ & $100 \%$ & $0 \%$ & $100 \%$ & ND & ND \\
\hline VAN $(30 \mu \mathrm{g})$ & ND & ND & ND & ND & $100 \%$ & $0 \%$ & ND & ND & ND & ND & $70 \%$ & $30 \%$ \\
\hline ERY $(15 \mu \mathrm{g})$ & ND & ND & ND & ND & ND & ND & ND & ND & ND & ND & $25 \%$ & $75 \%$ \\
\hline OFL $(5 \mu \mathrm{g})$ & ND & ND & ND & ND & ND & ND & ND & ND & ND & ND & $22 \%$ & $78 \%$ \\
\hline
\end{tabular}

All the experiments have been done three times and the results were reproducible. One representative data have been shown. ${ }^{\mathrm{a}} \mathrm{AMP}$ - Ampicillin, CIP Ciprofloxacin, PIP - Piperacillin, CEF - Ceftriaxone, AMO - Amoxicillin, IPM - Imipenem, PEN - Penicillin, CHL- Chloramphenicol, TMP/SUL Trimethoprim-sulfamethoxazole, GEN - Gentamicin, AZI - Azithromycin, KNA - Kanamycin, NALI - Nalidixic acid, VAN - Vancomycin, ERY Erythromycin, OFL - Ofloxacine. R - Resistant. S - Sensitive. ND - Not done.

\section{Gala apple samples}
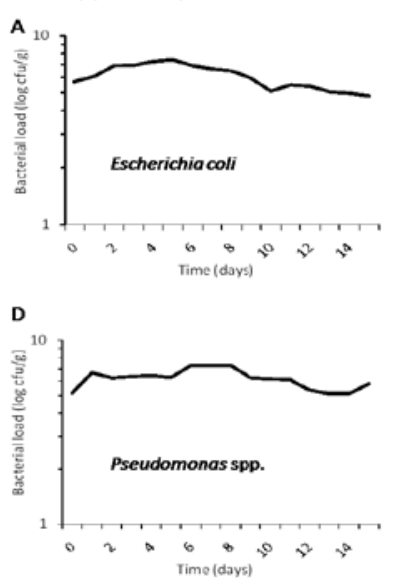

Golden Delicious apple samples
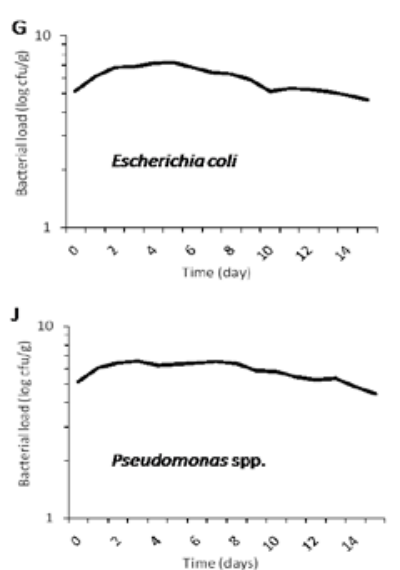
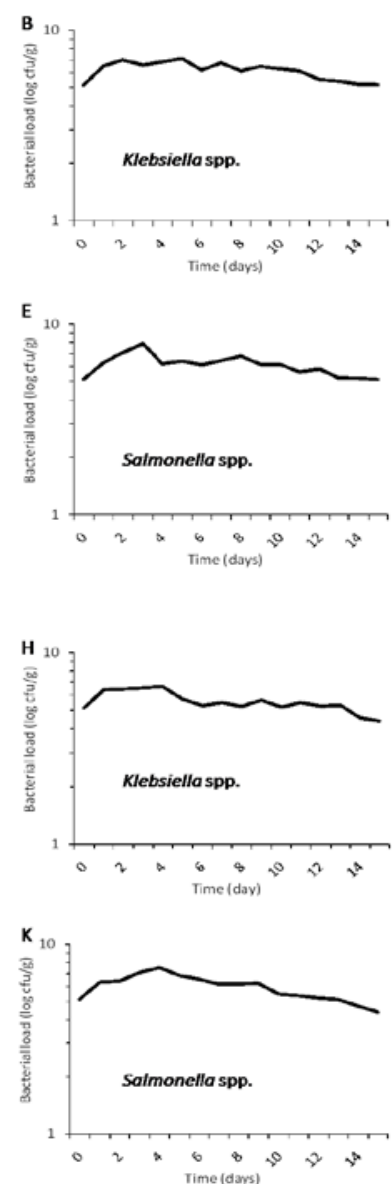
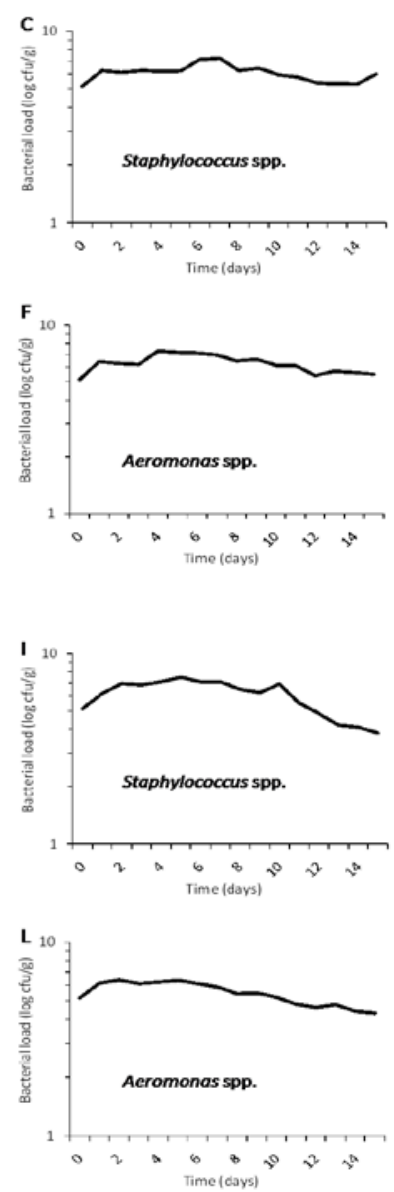

Figure 1. Bacterial Survival of in Gala (A - F) and Golden Delicious (G - L) apple samples. The turbidity of bacterial culture (A, G: Escherichia coli, B, H: Klebsiella spp., C, I: Staphylococcus spp., D, J: Psuedomonas spp., E, K: Salmonella spp., F, L: Aeromonas spp.) were adjusted with the standard solution of McFarland ( $\left.\mathrm{OD}_{600} 0.5\right)$ and then inoculate into the processed apple samples as described in Materials and Methods. Bacterial enumeration was done by the determination of colony forming units per gram of samples (cfu/g) on LB plates at every 24 hours interval up to 15 days. Experiments were performed 3 times independently and the results were reproducible. One representative data have been shown 
Interestingly, Staphylococcus spp. was found to be significantly reduced in the Golden Delicious samples, estimated to be reduced more than 3-log (Figure 2A). Consistently, the \%reduction for Staphylococcus spp. was also noticed to be higher in the Golden Delicious samples rather than the Gala ones (Figure 2B). More than 2-log reduction was noticed for Salmonella spp., E coli, and Klebsiella spp. Aeromonas and Pseudomonas spp. were found to be reduced more than 1-log in the Golden Delicious samples (Figure 2A).

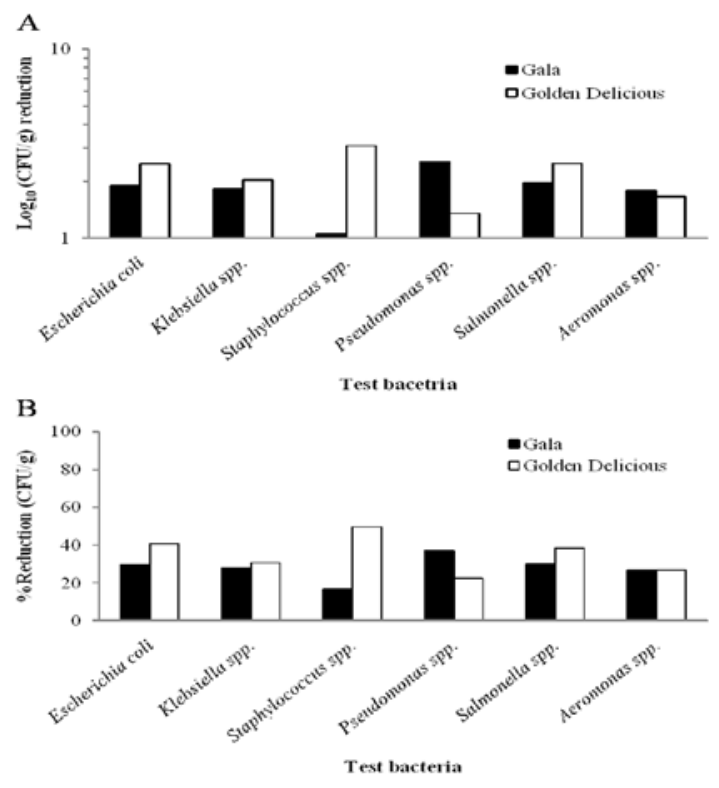

Figure 2. Reduction in bacterial growth (CFU/g) in Gala and Golden Delicious apple samples. A. $\log _{10}$ reduction, B. \%reduction

\section{Discussion}

Disease emergence due to health unconsciousness, unhygienic sanitation, water and environment pollution, inappropriate medication, and microbial contamination of food is common especially in the developing countries $[12,28,37]$. An increment to this detrimental situation has been mediated by the extensively drug-resistance phenomenon of the contaminating bacterial population $[9,13,37,38,39]$. As evident from the earlier investigations, most of the enteric diseases are significantly caused by contaminated food and water, evidently suggestive of harboring potential microbial pathogens [12,28,32,37,40,41]. Current study is in consistence since a huge number of bacterial pathogens and fungi have been isolated from the apple samples tested. Interestingly, the microbial contamination was highly significant in the surface portions of the samples other than the body and the core portions (Table 1). The probable cause of such contamination might be the entry of spoiling microorganisms into the fruits due to the lack of proper handling and effective antimicrobial treatments at every point of processing and even during consumption. Using contaminated water for washing purpose in the retailer shop and before consumption might also play a role.

From our study, the demonstration of drug-resistance of the drug-resistant bacteria in the samples is of public health significance. In real, in the developing countries, the antibiotic resistance rates have been found tremendously high due to the misuse, inappropriate selfmedication, and increased consumption of non-prescribed antibiotics [13]. Result from the present study is suggestive enough on the possible dissemination of drugresistance genes in the echo-system which in fine may create a serious medication complicacy during food borne diseases outbreaks.

An interesting finding of the current study is imposed on the anti-bacterial traits of the Golden Delicious apple samples. Though only one sample from this study was found to exhibit such trait against only one type of bacterium, Vibrio spp., yet this result urges an importance of hygienic handling of apple samples after harvesting and during distribution so that the product could be microbiologically safe with a natural medication properties. Several studies suggested that the presence of microorganism-killing agent in different food items could be a potential replacement of chemical medicines which indeed goes a long way to minimize the possible side effects of synthetic medicines, as well as may enhance the shelf life of the food and the consumer safety [15,16,42]. In the context of Bangladesh, this sort of demonstration in case of apple samples have been conducted for the first time, and eventually further experiments with more samples would probably fortify the natural means of disease mitication.

The last phase of the study was to assess the growth and survival potential of microorganisms in the samples studied for spoilage extent as already described. The investigation employed the microbiological challenge tests in vitro for the first time in fruits research in Bangladesh. Truly the information on the survival capacity of apple spoiling bacteria is limited till date. Nevertheless such knowledge could be useful in optimizing the apple storage and distribution period as well as the shelf life, and hence may contribute further to the overall knowledge on food safety and quality [20].

Challenge tests are commonly known to be performed on pharmaceutical product [43]. However, such sort of in vitro approach in case fruit microbiology, would be additive to demonstrate the ability of these products to serve as microbial substrate, which in turn, could minimize the risk of food poisoning [17]. Thus, based on such assumptive logic and suggestive importance to examine the microbiological quality of apples and their ability to maintain or eliminate microorganisms in course of time, we estimated the longevity of the culturable microorganisms in the apple samples. In developing countries, this sort of research especially in case of apples is still in its infancy [28,44,45,46]. However, the results of our investigation clearly showed an average of 1 logreduction of microorganisms in all samples, with a relatively higher reduction frequency of Gala samples in case of the ebiquitous Pseudomonas spp. The reduction of other bacteria in this sample was also not ignorent and hence the overall data sufficiently met the objective of the current study. The highest reduction of Staphylococcus spp. in the Golden Delicious apple samples could be assumptive of possible nutrient limiting situation in the samples for that very bacterium. Others were found to be reduced by an average of 2-log which is also predictive of the product quality profile after two weeks storage condition. Thus, as has been found in our study, the capacity of apples to influence microbial growth and 
proliferation would largely contribute to the sustaining food quality and stability as well as establishing shelf life.

Overall, our investigation portrayed a complete microbiological profile of the imported apples whose knowledge would bring the remedies to ease the burden of food borne illnesses in a specified community, thus imparting improvement in the public health sector. The primary research described here can be imitated in resource poor settings devoid of the facilities to conduct the extensive molecular studies on microbial virulence genes, toxins or metabolites, and the growth promoting factors. Finally, our study of microbial growth simulation in controlled condition in the apple samples could be great interest to predict the product quality and shelf-life as well as the consumer safety. Similar studies on different fruit items would further unveil the microbial growth harmony in accordance with the fruit type, which in turn, may draw the insight of the products' ability to support or repress the contaminating microbial proliferation.

\section{Acknowledgement}

We thank Stamford University Bangladesh for the technical facilities and financial support.

\section{Conflict of Interest}

Authors have no conflict of interest.

\section{References}

[1] Le Marchand, L., Murphy, S., Hankin, J., Wilkens, L. and Kolonel, L., "Intake of flavonoids and lung cancer", J Natl Canc Inst, 92, 154-160, 2000.

[2] Boyer, J. and Liu, R.H., "Apple phytochemicals and their health benefits”, Nutri J, 3 (1), 5, 2004.

[3] Chen, L., Ingham, B.H. and Ingham, S.C., "Survival of Penicillium expansum and patulin production on stored apple after wash treatments", J Food Sci, 69, 669-675, 2004.

[4] Mukhtar, A., Gilani, A.H. and Bhatty, N., "Some nutritional and microbiological aspects of apples of common varieties available for household consumption”, J Anim Plant Sci, 20 (4), 253-257, 2010.

[5] Olaimat, A.N. and Holley, R.A., "Factors influencing the microbial safety of fresh produce: A review”, Food Microbiol, 32, 1-19, 2012.

[6] Mudgil, S., Argawal, D. and Ganguli, A., "Microbiological analysis of street vended fresh squeezed carrot and Kinnow Mandarin juice in Patiala City. India”, Internet J Food Safety, 3, 13, 2004.

[7] Aycicek, H., Oguz, U. and Karci, K., "Determination of total aerobic and indicator bacteria on some raw eaten vegetables from whole sellers in Ankara. Turkey”, Int J Hyg Environ Health, 209, 197-201, 2006.

[8] Eni, A.O., Oluwawemitan, I.A. and Oranusi, U.S., "Microbial quality of fruits and vegetables sold in Sango Ota, Nigeria”, Afr J food Sci, 4 (5), 291-296, 2010.

[9] Tenover, F.C., "Mechanisms of antimicrobial resistance in bacteria”, American J. Med, 119 (2), 3-10, 2006.

[10] Mathew, A.G., Cissell, R. and Liamthong, S., "Antibiotic resistance in bacteria associated with food animals: a United States perspective of livestock production“, Foodborne Path Dis, 4 (2), 115-133, 2007.

[11] Allerberger, F. and Mittermayer, H., "Antimicrobial stewardship“, Clin Microbiol Infect, 14 (3), 197-199, 2008.

[12] Acharjee, M., Rahman, F., Jahan, F. and Noor, R., "Bacterial proliferation in municipal water supplied in mirpur locality of
Dhaka city, Bangladesh. CLEAN- Soil, Air, Water, 2013. www.doi.org.10.1002/clen.201200618.

[13] Dutta, S., Hassan, M.R., Rahman, F., Jilani, M.S.A. and Noor, R., "Study of antimicrobial susceptibility of clinically significant microorganisms isolated from selected areas of Dhaka, Bangladesh”, Bang. J Med Sci, 12 (1), 34-42, 2013.

[14] Khan, S.A., Feroz, F. and Noor, R., "Study of extended spectrum $\beta$-lactamase producing bacteria from urinary tract infection in Dhaka city, Bangladesh”, Tzu Chi Med J, 25 (1), 39-42, 2013.

[15] Dubey, A., Mishra, N. and Singh, N., "Antimicrobial activity of some selected vegetables”, Int J Appl Biol Pharma Technol, 1 (3), 994-999, 2010.

[16] Hussain, A., Wahab, S., Zarin, I. and Hussain, M.D.S., "Antibacterial activity of the leaves of Coccinia indica (W. and A) of India”, Adv Biol Res, 4 (5), 241-248, 2010.

[17] Notermans, S. and Veld, P., "Microbiological challenge testing for ensuring safety of food products”, Int J Food Microbiol, 24 (1-2), 33-39, 1994.

[18] Scott, V.N., Swanson, K.M. J., Freier, T.A., Pruett, W.P., Sveum, W.H., Hall, P.A., Smoot, L.A. and Brown D.G., "Guidelines for conducting Listeria monocytogenes challenge testing of foods", Food Prot Trends, 25 (11), 818-825, 2005.

[19] NACMCF (National Advisory Committee on Microbiological Criteria for Foods), "Parameters for determining inoculated pack/challenge study protocols”, J Food Prot, 73 (1), 140-202, 2005.

[20] AFSSA (Agence Franc,aise de Se'curite' Sanitaire des Aliments), "Technical guidance document on shelf-life studies for Listeria monocytogenes in ready-to-eat foods”, 2008. Available at: http://ec.europa.eu/food/food/biosafety/salmonella/docs/shelflife_ listeria_monocytogenes_en.pdf (Accessed 18 August 2013).

[21] Juhneviča, K., Skudra, G. and Skudra, L., "Evaluation of microbiological contamination of apple fruit stored in a modified atmosphere”, Environ Exp Biol, 9, 53-59, 2011.

[22] Oranusi. U.S. and Wesley. B., "Microbiological safety assessment of apple fruits (Malus domestica Borkh) sold in Owerri Imo State, Nigeria”, Adv J Food Sci Tech 4 (2), 97-102, 2012.

[23] American Public Health Association (APHA), Standard methods for the examination of water and wastewater, American Public Health Association, Washington, D.C., 1998.

[24] Cappuccino, J.G. and Sherman, N., Microbiology - A Laboratory Manual, The Benjamin/Cummings Publishing Co., Inc., Menlo Park, California, 1996.

[25] Polcovnicu, C., Ionescu, L. and Bahrim, G., "Confirmation and identification of Listeria species from fresh lettuce”, Romanian Biotechnol Let, 13 (6), 32-36, 2008.

[26] Colwell, R.R., Non-culturable microorganisms in the environment, American Society of Microbiology, Washington DC, USA, 2002, 325-342.

[27] Oliver, J.D., "Recent findings on the viable but nonculturable state in pathogenic bacteria”, FEMS Microbiol. Rev, 34, 415-425, 2010.

[28] Rahman. F. and Noor, R., "Prevalence of pathogenic bacteria in common salad vegetables of Dhaka metropolis”, Ban J Bot, 41 (2), 150-162, 2012.

[29] Alfrad, E.B., Bensons Microbiological Applications, Mcgraw-Hill Book Company, New York, 2007.

[30] Bauer, A.W., Kirby, W.M.M., Sherris, J.C. and Tierch, M., "Antibiotic susceptibility testing by a standardized single disc method”, American J Clin Pathol, 45 (4), 493-496, 1998.

[31] Ferraro, M.J., Craig, W.A. and Dudley, M.N., Performance standards for antimicrobial susceptibility testing, NCCLS, Pennsylvania, USA, 2011.

[32] Munshi, S.K., Rahman, M.M. and Noor, R., "Detection of virulence potential of diarrheagenic escherichia coli isolated from surface water of rivers surrounding Dhaka city”, J Bang Acad Sci, 36 (2), 109-121, 2012.

[33] Jagessar, R.C., Mars, A. and Gones, G., "Selective antimicrobial properties of leaf extract against various micro-organisms using Disc diffusion and Agar well diffusion method”, J Nat Sci, 6 (2), 24-38, 2008.

[34] Urmi, N.J., Ahmed, T., Acharjee, M., Das, K.K. and Noor, R.,'Microbiological analysis and detection of antibacterial activity of salad vegetables found in Dhaka metropolis, Bangladesh”, $J$ Pure Appl Microbiol, 2013. Accepted

[35] Adib, A.M., Ahmad, F. an Idris, M.S., "Synthesis and antimicrobial activity of 4',5,7-trihydroxy-3'-prenylflavanone”, $J$ Chem Sci, 120 (5), 469-473, 2008. 
[36] FDA (Food and Drug Administration), Microbiological challenge testing, 2008. Available at: http://www.fda.gov/Food/FoodScienceResearch/SafePracticesforF oodProcesses/ucm094154.htm (Accessed 25 August 2013).

[37] Noor, R., Acharjee, M., Ahmed, T., Das, K.K., Paul, L., Munshi, S.K., Urmi, N.J., Rahman, F. and Alam, Z., "Microbiological study of major sea fish available in local markets of Dhaka city, Bangladesh”. J Microbiol Biotechnol Food Sci, 2 (4), 2420-2430, 2013.

[38] Raz, R., Edelstein, H., Grigoryan, L. and Haaijer-Ruskamp, F.M. "Self-medication with antibiotics by a population in Northern Israel”, Isr Med Assoc J, 7 (11), 722-725, 2005.

[39] Chowdhury, M.A.K.A., "Evolving antibiotic resistance: A great threat to medical practice”, Bangl. J Med Sci, 11 (1), 1-3.

[40] Butt, A.A., Aldridge, K.E. and Sanders, C.V., "Infections related to the ingestion of seafood part 1: viral and bacterial infections", Lacent Infectious Diseases, 4, 201-212, 2004.

[41] Mahbub, K.R., Nahar, A., Ahmed, M.M. and Chakraborty, A., "A quality analysis of Dhaka WASA drinking water: detection and biochemical characterization of the isolates", Journal of Environmental Science and Natural Resources 4 (2): 41-49, 2011.

[42] Kyung, K.H. and Fleming, H.P., "Antibacterial activity of cabbage juice against Lactic Acid bacteria”, J Food Sci 59 (1), 125-129, 1994.

[43] Manou, I., Bouillard, L., Devleeschouwer, M.J. and Barel, A.O., "Evaluation of the preservative properties of Thymus vulgaris essential oil in topically applies formulations under a challenge test”, J Appl Microbiol, 84 (3), 368-367, 1988.

[44] Beuchat, L.R., "Pathogenic microorganisms associated with fresh produce”, J Food Prot, 59 (2), 204-216, 1996.

[45] Abadias, M., Usall, J., Anguera, M., Solsona, C. and Viñas, I, "Microbiological quality of fresh, minimally processed fruit and vegetables, and sprouts from retail establishments", Int J Food Microbiol, 123 (1-2), 121-129, 2008.

[46] Cordano, A.M. and Jacquet, C., "Listeria monocytogenes isolated from vegetable salads sold at supermarkets in Santiago, Chile: Prevalence and strain characterization”, Int J Food Microbiol, 132 (2-3), 176-179, 2009. 